\title{
REVIEW
}

\section{Regulation of HIV and HTLV gene expression}

\section{Harold Varmus \\ Departments of Microbiology and Immunology and Biochemistry and Biophysics, University of California School of Medicine, San Francisco, California 94143 USA}

Until recently, simplicity and uniformity of design appeared to be universal features of retroviruses. Most retroviruses thrive with a few open reading frames in their genomes, all devoted to major constituents of virus particles: core proteins, envelope glycoproteins, and virionassociated catalytic proteins (reverse transcriptase, integrase, and protease). In the life cycle of the usual retrovirus, there is a straightforward division of labors: early events depend largely upon viral reverse transcriptase and integrase, whereas in the later stages components provided mainly by the host are harnessed for production of viral proteins and progeny particles /Varmus and Swanstrom 1982, 1985).

Over the past few years, close study of two types of human retroviruses, the T-cell leukemia viruses (HTLVI and -II) and the immunodeficiency viruses (HIV-1 and -2), has uncovered a multiplicity of unexpected viral regulatory functions, now forcing a revision of this traditional view of the retrovirus life cycle. The newly discovered functions are fascinating mechanistically and mysterious evolutionarily. Moreover, they offer promise of understanding some perplexing physiological aspects of infection with major clinical consequences-latency and reactivation of $\mathrm{HIV}$ and inefficient leukemogenesis by HTLV.

The most prominent regulatory genes in the two types of virus (tat and rev of HIV and tax and rex of HTLV) are profoundly different from a biochemical perspective, but their ultimate effects on gene control are provocatively similar: tat and tax augment viral gene expression generally, most clearly by increasing concentrations of viral RNA; rev and rex favor production of viral structural over regulatory proteins by altering the proportions of unspliced to fully spliced mRNA. These functions are not confined to human retroviruses: Animal viruses related to the HTLVs [e.g., bovine leukemia virus (BLV) and simian T-cell leukemia viruses (STLV)] and to the HIVs [e.g., simian immunodeficiency virus (SIV) and visna virus] appear to encode proteins similar to those encoded by the human prototypes.

Although the existence and importance of the newly discovered retroviral regulators are beyond doubt, an un-

The control of HIV gene expression, organized by F. Wong-Staal, R. Franza, and B. Cullen, was held February 28 to March 2, 1988, at the Banbury Center, Cold Spring Harbor Laboratory. A volume, The control of HIV expression (eds. B.R. Franza, Jr., B.R. Cullen, and F. Wong-Staal), containing about 30 papers written by contributors to the meeting was be published in July, 1988, by Cold Spring Harbor Laboratory and contains full citations for the large body of work summarized here. derstanding of their functions has been impeded by conflicting results, confusing nomenclatures, possible multiplicities of action, and a dearth of mechanistically incisive experiments. In an effort to confront some of these problems head-on, the Banbury Center at the Cold Spring Harbor Laboratory recently invited most of the major players, as well as several investigators concerned with more general issues of transcriptional control or retrovirus replication, to hash out differences and discuss new findings. Predictably enough, many important questions remained unresolved, but a semblance of consensus also emerged about what could be accepted as fact, what names should be adopted for some of the genes, and what issues should be given experimental priority. The following is one observer's view of that consensus.

\section{Novel genes in the HIV genome}

There is now evidence for five or more novel genes in HIV genomes, in addition to those (gag, pol, and env) encoding proteins found universally in retroviral particles. At least three of these, tat, rev, and nef, have been strongly implicated in the regulation of HIV gene expression and are discussed in detail below; others have no identified function as yet $(v p r, v p x)$ or augment virus infectivity in unknown ways (vif). To the consternation of outside observers, some of these novel genes have been called by as many as a half dozen different names. Shortly after the Banbury Center meeting, an agreement was reached on the terms to be used for these genes (Gallo et al. 1988). The recommendations are summarized in Table 1 and followed in the text.

\section{Viral regulators}

tat

The tat gene is a powerful trans-activator of HIV gene expression at one or more levels of control (Sodroski et al. 1985a; Cullen 1986; Rosen et al. 1986) and is essential for virus growth (Dayton et al. 1986; Fisher et al. 1986a). Unlike virtually all other retroviral genes, tat splits its coding sequence into two exons (see Fig. 1), which in the most commonly used virus strain encode an 86-amino-acid protein (Tat) found mostly in the nucleus (Arya et al. 1985; Sodroski et al. 1985b; Hauber et al. 1987). The protein sequence is rich in cysteines and 
Table 1. Regulatory genes in human retroviral genomes

\begin{tabular}{|c|c|c|}
\hline Virus group & New names & Old names \\
\hline \multicolumn{3}{|c|}{ Immunodeficiency } \\
\hline \multirow[t]{6}{*}{ viruses } & tat & tat-III, TA \\
\hline & rev & trs, art \\
\hline & nef & $\begin{array}{l}3^{\prime} \text { orf, orf }-\mathrm{B} \text {, orf }-\mathrm{F} \text {, } \\
\mathrm{E} \text {, orf }-2\end{array}$ \\
\hline & vif & $\begin{array}{l}\text { sor, orf- } \mathrm{A}, \text { orf }-\mathrm{Q}, \mathrm{P}^{\prime} \text {, } \\
\quad \text { orf- } 1\end{array}$ \\
\hline & $v p r$ & $\mathbf{R}$ \\
\hline & $v p x$ & $\mathbf{X}$ \\
\hline \multicolumn{3}{|c|}{ T-cell leukemia } \\
\hline \multirow[t]{2}{*}{ vinuses } & $\operatorname{tax}$ & $\begin{array}{l}\mathbf{x}, \mathbf{x}^{\mathrm{I}}, \text { tat-I, tat-II, } \\
\quad \mathrm{x}-\text { lor }\end{array}$ \\
\hline & rex & $x^{\text {III }}$ \\
\hline
\end{tabular}

New names as proposed by Gallo et al. (1988). (tat) Trans-activator; $(\mathrm{rev})$ regulator of expression of virion proteins; (nef) negative factor; (vif) virion infectivity factor; (vpr) virion protein $\mathrm{R}_{\text {; }}$ $(v p x)$ virion protein $\mathrm{X}_{;}(\operatorname{tax})$ trans-activator from $\mathrm{x}_{;}(\mathrm{rex})$ regulator of expression from $x$.

basic residues, but most of the latter are dispensible for activity, whereas most of the cysteines appear, from recent site-directed mutagenesis experiments, to be crucial for function (F. Wong-Staal, National Institutes of Health; C. Rosen, Roche Institute; Sadaie et al. 1988). The cysteines are likely to mediate binding to heavy metals (Rosen; Wong-Staal), but rather than form the zinc fingers characteristic of certain DNA-binding proteins, the metal binding appears to promote dimerization (Frankel et al. 1988).

Whether assessed for its effects on expression of an intact provirus or, more commonly, on expression of chimeric reporter genes [e.g., HIV LTR-CAT (chloramphenicol transacetylase)], tat may show induction ratios as high as 1000 or more. The magnitude of the effect varies widely, however, and is especially dependent on choice of host cells. (Mouse fibroblasts allow much smaller inductions than do human $T$ cells, and the human colon carcinoma line, SW480, may have an endogenous tat-like activity that precludes a response to viral tat.) Results are also likely to be strongly influenced by the concentration of an exogenous responsive gene, the experimental strategy (e.g., transient versus stable transfections), and perhaps by other less tangible factors.

These differences, often invoked in the Banbury discussions, may account for some radically different views of tat function. For example, effects upon the concentration of reporter protein often exceed the increase in cognate RNA, suggesting that there might be more than one mechanism by which Tat works; but in many other experiments (e.g., Rice and Mathews 1988), the concentrations of reporter RNA and protein rise in equal proportion. Discordance between tat induction of RNA and

\section{HUMAN T-LEUKEMIA VIRUSES}

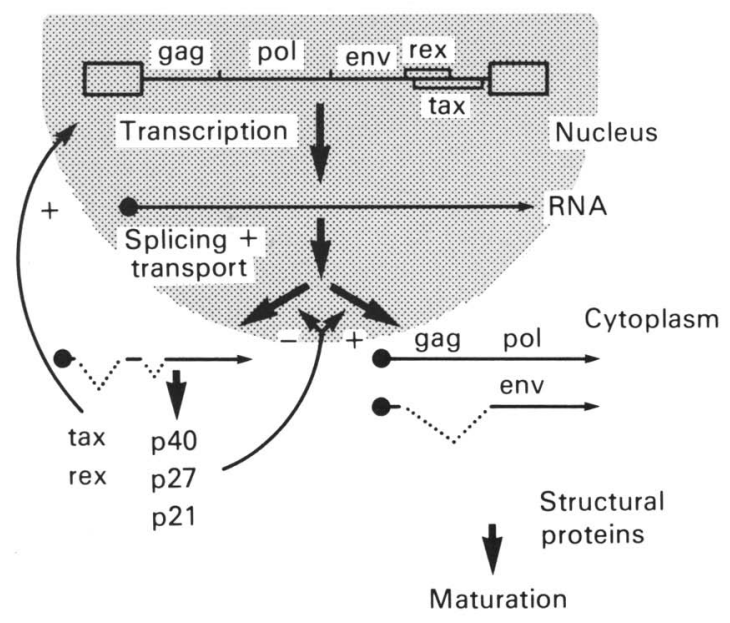

Yoshida, 1988.

\section{HUMAN IMMUNODEFICIENCY VIRUSES}

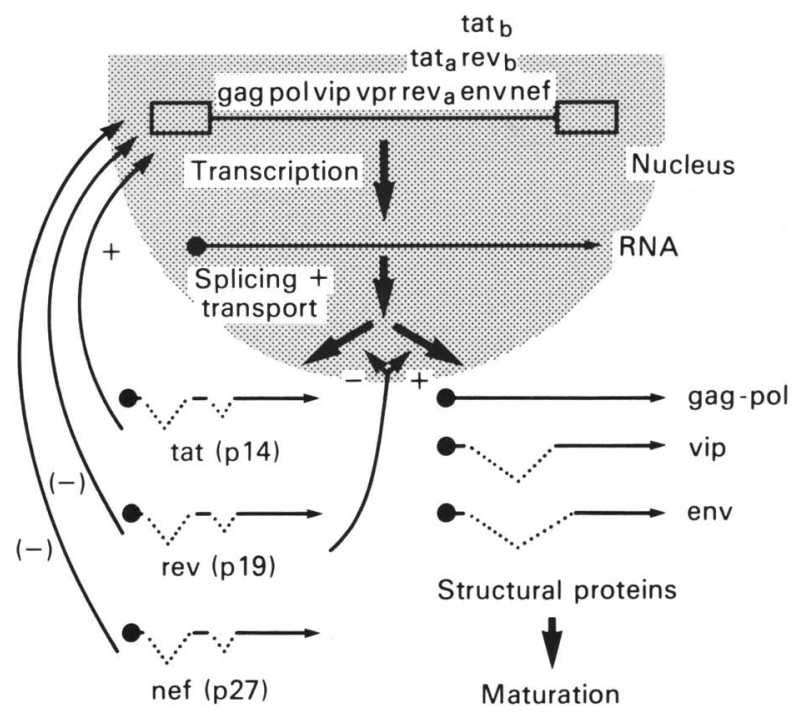

Wong-Staal, 1988.

Figure 1. The organization and expression of regulatory genes of human retroviruses. The diagrams (provided by M. Yoshida and F. Wong-Staal) illustrate many of the aspects of retroviral gene expression discussed in the text. Transcription of HTLV and HIV proviruses produces genome-length precursors, which are differentially spliced to generate mRNAs for structural proteins (encoded by gag, pol, env, and vif [labeled vip in this figure]) and nonstructural, regulatory proteins (encoded by tax, rex, tat, rev, and nef). Strong positive and negative effects upon steps in the life cycle are indicated by + and - , weak negative effects are indicated by $(-)$. 
protein suggests that tat may affect other processes [e.g., RNA trafficking or translation efficiency (W. Haseltine, Harvard|], as well as accumulation of RNA.

One way to approach the mechanism (or mechanisms) by which Tat works is to define the phenomena more carefully than has been done. It was disappointing to learn, for example, that no serious effort has been made to follow the metabolism of RNA from a tat-regulated gene, thereby defining its association with subcellular structures, including polyribosomes.

Another, better-exploited approach is through the definition of targets for Tat. There is general agreement that most or all of the effect(s) of Tat are mediated through the first 80 nucleotides of HIV normally transcribed to form the $5^{\prime}$ end of viral RNA (Rosen et al. 1985; Muesing et al. 1987; Hauber and Cullen 1988), a region now known as TAR (for 'Tat response'). More refined mutagenesis suggests that only the first 44 nucleotides of TAR are required for most of its activity, at least as measured in assays of RNA (B. Cullen, Duke University; D. Capon, Genentech; M. Peterlin, University of California, San Francisco). The TAR sequences of HIV-1 and HIV-2 RNAs can be drawn as complex stem-loops of somewhat different shapes. However, the TAR sequences are not interchangeable: Tat encoded by HIV-1 will work on both TARs, but HIV-2 Tat functions efficiently only on its homologous TAR (M. Emerman, Pasteur Institute; Emerman et al. 1987).

HIV-1 RNA structure in the TAR region has been validated partially by nucleases (Capon) and compensatory mutations (Holland, Stanford), but it remains uncertain whether TAR functions in the form of DNA or RNA. Tat binds nonspecifically to polynucleotides, so direct binding assays have not been helpful. Two new results favor the idea that the target is RNA. (1) A site-directed mutation predicted to destabilize the stem in TAR RNA negatively affects the response to Tat, and the response can be restored with a compensatory mutation on the other side of the stem (Holland). (2) Labeled, TAR-containing short RNAs show retarded gel mobility after incubation in extracts from tat-expressing $\mathrm{CHO}$ cells, but not after incubation in extracts from control cells (experiments described in discussion by C. Rosen, Roche Institute, performed in collaboration with N. Sonenberg, Montreal). Though neither of these findings should be considered definitive, it is attractive to think that TAR works as RNA. This could provide rationalizations for the strong and conserved secondary structure predictions, the dependence of TAR upon its position downstream of the transcriptional start, and the possibility of multiple effects of Tat during gene expression.

Defining the target for Tat, of course, does not define the mechanism of action. Of the many possibilities that have been aired, perhaps the greatest attention has been given recently to the proposal that Tat acts as an antiterminator of transcription (Kao et al. 1987), a proposal that accounts for the efficient accumulation of an approximately 60-nucleotide $5^{\prime}$ segment of HIV RNA in the absence of Tat and for its replacement by longer RNA in the presence of Tat (Peterlin). Detractors point out that the observed RNA species is predicted to have a high degree of secondary structure and might be the expected residuum of degradation. In addition, an antitermination mechanism predicts that deletion of the termination site will yield constitutive 'up' mutants, yet no such mutants have been isolated. Thus, proposals that Tat affects initiation, RNA processing, or RNA stability still have currency - and may be testable with a Tat-responsive in vitro transcription system (Okamoto and Wong-Staal 1986).

Though the regulatory effects of Tat appear to be novel viral phenomena, DNA-damaging agents (mitomycin, UV irradiation) induce cellular effects that mimic Tat activity on heterologous genes linked to HIV sequences and on production of HIV itself (Rosenberg, Smith-Kline-Beckman; Valerie et al. 1988). Thus, normal cells may have genetic analogs of tat that remain to be isolated.

rev

The product of rev is also a small nuclear protein $(\operatorname{Rev})$, encoded by two exons, and essential for virus growth (Feinberg et al. 1986; Sodroski et al. 1986). The best assessment of its function is based upon the phenomenological consequences of lethal mutations: Viral structural proteins are not made in detectable amounts and the proportional representation of HIV mRNAs is sharply skewed in favor of the doubly spliced mRNAs for tat, rev, and nef (Wong-Staal; Rosen; G. Pavlakis, Frederick Cancer Research Facility; Feinberg et al. 1986). This implies that the major role of the gene is to sustain the production of unspliced (gag and gag-pol) and partially spliced (env) mRNAs, at the expense of mRNAs for the regulatory proteins. This seems paradoxical, since continued synthesis of Tat might be required for maintaining high levels of viral RNA in virus-producing cells. It appears possible, however, to produce an active form of Tat, even from the incompletely spliced RNA found in the presence of Rev, because Tat function is retained after deletion of its second coding exon. A conserved stop codon near the $5^{\prime}$ end of the preceding intron insures that Tat made from incompletely spliced RNA will not include carboxy-terminal sequence from the intron (Cullen).

The analysis of HIV sequences that act in cis to determine responsiveness to Rev makes TAR seem simple indeed (Pavlakis; Rosen; Haseltine). There appear to be several regions, mostly within env, but also upstream of $e n v$, that act as targets for unknown cellular factors that somehow repress expression of HIV or heterologous genes in the same transcriptional unit. Another sequence, again within $e n v$, is required for Rev to relieve the repression (Rosen et al. 1988). Both types of targets thus reside within one of the introns (largely composed of $e n v$ ) that Rev spares from splicing in the virus life cycle.

Though intriguing, these facts do not say much about mechanism. Experiments performed with transcripts devoid of wild-type splicing signals have been used to lo- 
calize both the 'repressive' sequences and those that serve as targets for Rev-dependent release of repression, implying that apparent effects upon splicing of HIV RNA might be mediated through direct effects upon other aspects of RNA metabolism or transport (Rosen et al. 1988). Changes in mRNA concentrations do not seem to account fully for the abundance of viral proteins; thus there may be additional effects on translation (Pavlakis).

nef

nef is a dispensible gene; indeed mutants overproduce virus by several fold (Luciw et al. 1987), suggesting that the normal function of its protein (Nef) is negative regulation, partly balancing the effects of Tat and perhaps contributing to the development of virus latency. [There is some evidence that Rev may also have a weak negative effect on transcription (Wong-Staal; Sadaie et al. 1988), but other labs claim this effect is not specific for the HIV LTR.]

It is far from clear how the negative effects of nef are produced, although they are apparent from heightened production of both viral RNA and mature virus in cells infected with nef mutants and from reduced levels when such mutants are complemented with nef expression vectors (S. Venkatessan, National Institutes of Health). Most speculation centers around the unexpected characteristics of one of the two proteins initiated from nearby ATGs in the single coding exon. This version of Nef is a myristylated, $27-\mathrm{kD}$ protein that associates with plasma membranes and resembles ras and $\mathrm{G}$ proteins by virtue of certain sequence motifs and biochemical properties (GTP binding and hydrolysis) (Guy et al. 1987; Venkatessan). It should soon be apparent whether the resemblance to components of signal transduction pathways is more than coincidental, and perhaps instructive for those studying control of cell growth.

\section{The tempo of HIV growth}

Understandably, most studies of the three major regulators of HIV have been conducted with cloned components, genetic hybrids, and heterologous cells, yet there is a strong need to interpret the findings in the contexts of the virus life cycle and its pathogenic mechanisms in the host. As Figure 1 and the foregoing discussion suggest, the products of tat, rev, and nef have the potential to act through a system of checks and balances to establish a steady-state level of virus production. Tat may insure adequate concentrations of the primary viral transcript, Rev may insure that the RNA will be apportioned properly among the mRNAs for structural and nonstructural proteins, and Nef may insure that expression will not become too robust overall. It is more difficult to predict the dynamics of viral gene expression before any steady state is achieved, but it is reasonable to imagine a temporal sequence in which Tat has precedence at earliest times and Rev comes into its own later to guarantee a supply of mRNA for virion proteins.

It is also difficult to gauge the extent to which the viral regulatory scheme is influenced by the availability of host regulatory factors, especially those that affect transcription from the HIV LTR. Such factors are likely to be decisive about the overall level of viral gene expression, ranging from latency to full-blown production of virus. Latency is of particular interest in the study of HIV, because the virus is cytolytic in some cell types; hence the latently infected cell may constitute a major reservoir of viral genes in an infected host.

It is not known how latency is established (e.g., whether latently infected cells were transiently virusproducers), but the pathway out of latency is easier to investigate and seems likely to depend upon the activation of host transcription factors (e.g., via stimulation of $\mathrm{T}$ cells with antigens, mitogens, or phorbol esters) or upon infection with viruses, such as herpes viruses (Gendelman et al. 1986; Mosca et al. 1987; Siekevitz et al. 1987; J. Mosca, Johns Hopkins), that encode trans-activators competent to interact with the HIV LTR. This proposal has focused attention on multiple cellular and nonretroviral transcription factors.

\section{Host transcription factors}

The 200 or so base pairs surrounding the initiation site for transcription in the HIV LTR appear to be densely populated with binding sites for host proteins thought to promote transcription by RNA polymerase II. Proceeding upstream from the start site, there are consensus sequences for the TATA binding factor (TFIID; R. Roeder, Rockefeller Univ.), SP1 (Jones et al. 1986; J. Kadonga, University of California, Berkeley), AP1 (R. Franza, Cold Spring Harbor Laboratory), NF- $\mathrm{kB}$ (Dinter et al. 1987; Kaufman et al. 1987; Nabel and Baltimore 1987; P. Baeuerle, Whitehead Institute), and perhaps several other, less well-studied factors (Franza et al. 1987; Garcia et al. 1987; Wu et al. 1988). Downstream of the start site, overlapping the TAR region, there are binding sites for at least two other proteins, nuclear factor-1 (NF1 or CTF) and a leader binding protein (LBP) (K. Jones, Salk Institute; Jones et al. 1988).

For the most part, it is difficult to gauge the contributions made by each of these to the constitutive level of expression, in part because the intrinsic activity of the HIV promoter remains poorly defined. Moreover, interactions (if any) between the host and viral regulators are not known; for instance, analysis of TAR mutants argues that CTF binding is not related to tat function, but LBP binding might be (Jones).

Given these uncertainties, particular attention has been focused upon NF-kB, because the activation of this factor accompanies T-cell activation and is therefore considered likely to have a major role in the escape from viral latency under physiological conditions (Kaufman et al. 1987; Nabel and Baltimore 1987; W. Greene, Duke University|. It has been known for some time that protein synthesis is not required for the appearance of NF- $\mathrm{kB}$ activity in cells treated with phorbol esters (Sen and Baltimore 1987), implying that preformed protein is modified, perhaps by protein kinase $\mathrm{C}$. More recent 
work suggests a more complicated mechanism: The inactive form of NF- $\mathrm{KB}$ appears to be affiliated in the cytoplasm with another protein, a putative inhibitor; dissociation of the complex in vitro (e.g., with deoxycholate) delivers protein with the site-specific binding properties of NF-kB (Baeuerle). It will be of great interest to learn how the complex is dissociated under normal physiological conditions.

\section{Other factors in the HIV life cycle}

Although novel regulatory genes have properly attracted most of the recent attention as objects of scientific curiosity and as candidate targets for antiviral drugs, other aspects of the life cycles of HIV also have experimental and therapeutic potential. For example, the vif protein regulates the infectivity of HIV particles in some mysterious way (Fisher et al. 1987; Strobel et al. 1987); the viral protease governs necessary cleavages of gag and gag-pol polyproteins into their mature components (Farmerie et al. 1987); a sequence in the gag-pol overlap dictates a shift of reading frames essential for synthesis of viral enzymes (Jacks et al. 1988); complex interactions between the viral env protein and $\mathrm{CD} 4$ (and perhaps other host-encoded proteins; Maddon et al. 1986) are required for virus entry into cells and for activation of reverse transcription; and the viral integrase, a protein without known parallel in host cells, must carry out a precise recombination event to establish the provirus (Varmus and Brown 1988).

\section{Novel genes in the HTLV genome}

Overlapping open reading frames are found downstream from the env gene in the genomes of viruses in the HTLV family (Seiki et al. 1983). Thus far, regulatory functions have been assigned to two of them, now called tax and rex (Table 1; Yoshida and Seiki 1987). As shown in Figure 1, tax and rex proteins (Tax and Rex) appear to be synthesized from a single species of mRNA, using overlapping reading frames (Nagashima et al. 1986). The tax frame produces one protein of $40-42 \mathrm{kD}$, but rex yields at least two proteins of $\sim 27 \mathrm{kD}$ and $21 \mathrm{kD}$; functional studies of rex have concentrated upon the larger species.

\section{$\operatorname{tax}$}

As a strong trans-activator of viral gene expression (Sodroski et al. 1984), Tax resembles HIV Tat in its potential to contribute to the economy and pace of virus growth (Haseltine). However, in mode of action, it appears to have more in common with other known viral and cellular transcription factors. The portion of the HTLV genome that responds to Tax is positioned within the U3 region of the LTR, about $50-150 \mathrm{bp}$ upstream from the transcriptional start site, and composed of three copies of a 21-bp sequence, two of which are in tandem and the third separated from them by a $60-b p$ unit (J. Brady, National Institutes of Health; B. Felber,
Frederick Cancer Research Facility; Felber et al. 1985; Fujisawa et al. 1985; Paskalis et al. 1986; Brady et al. 1987); at least two adjacent copies of the repeat or one linked to the 60-bp unit are required for activity. This region has several properties characteristic of enhancer elements, such as relative position and orientation independence. Although Tax does not show binding specificity for its target and does not affect protection of the target in footprinting assays, the protein does appear to be a component of nucleoprotein complexes formed on the target sequence; a $180-\mathrm{kD}$ cellular protein appears to be a major component of the relevant binding activity on the 21-bp repeats (Brady). This suggests that Tax may act by modifying host transcription factors, in this sense resembling the E1A protein of adenoviruses (Chen et al. 1985a).

Inspection of the 21-bp repeats in HTLV-1, -2, and $B L V$, coupled with selective mutagenesis, implicate a consensus sequence (TGACG) in the response to Tax (Felber; Brady). The similarity to sequences that mediate a transcriptional response to cAMP has provoked a successful test of the idea that Tax can trans-activate the c-fos promoter, one known to be sensitive to cAMP (Felber). Other cellular genes, including those encoding interleukin- 2 and its receptor, have previously been judged responsive to Tax (Inoue et al. 1986, Marayuma et al. 1987; Siekevitz et al. 1987b; Cross et al. 1987).

The claim that tax is an essential gene for replication of HTLV is well supported by site-directed mutagenesis of an infectious clone of HTLV-2 DNA /Chen et al. 1985b|. But it has been difficult to explore the physiological role of Tax in the virus life cycle or its leukemogenic effects for a variety of reasons: An infectious clone of HTLV-1 has yet to be isolated, the HTLVs are very poorly infectious in cell culture, fresh tumor cells usually fail to express any viral genes, and attempts to transform cells with tax expression vectors have yet to succeed. Efforts have been made to circumvent some of these problems by producing transgenic mice carrying tax under the control of various promoters. Although some mice have developed tumors, the histological type (neurofibromas) was unexpected (Hinrichs et al. 1987), and many transgenic lines are tumor-free despite expression of tax (Felber).

rex

The $27-\mathrm{kD}$ product of the rex frame, Rex, appears to produce physiological consequences analogous to those of Rev: an increased proportion of those unspliced and partially spliced mRNAs required for synthesis of virion structural proteins, at the expense of the fully spliced tax/rex mRNA (Inoue et al. 1986, 1987; Hidoka et al. 1988). The target for this function, however it may operate, may be within the $3^{\prime}$ LTR (Yoshida, Japan Cancer Institute). There is also evidence for a second function of Rex, an interaction between Tax and Rex during control of transcription: at low levels, Rex augments trans-activation by Tax, but at high levels Rex is inhibitory (I. Chen, University of California, Los An- 
geles; Rosenblatt et al. 1988). (Rex does not trans-activate transcription from the HTLV LTR on its own.)

\section{Perspective}

The Banbury proceedings may have produced no momentous revelations, but they dramatized how swiftly a mini-discipline, with its own language and lore, has developed from the revolutionary findings that retroviruses may encode their own regulatory apparatus. Studies of the new HIV and HTLV genes and more established studies of cellular regulatory factors are proving to be synergistic, helping to involve a surprisingly large number of laboratories with the problems posed by pathogenic human retroviruses. Moreover, progress with human retroviruses is having effects on those working with the ostensibly simpler retroviruses of birds and rodents: A long overdue interest in the general problem of attaining an appropriate ratio of spliced to unspliced viral mRNA and renewed searches for unexplained open reading frames, however short, in viral genomes.

As this new field grows and wrestles with its most obvious goals - the intellectual goal of understanding regulatory mechanisms and the pragmatic goal of finding inhibitors of regulatory proteins - it may come to suffer from deficiencies in certain fundamentals. Among the missing items mentioned at the Banbury meeting are complete catalogs of HIV and HTLV mRNAs, an infectious clone of HTLV-1 proviral DNA, and a meticulous account of the distribution and turnover of HIV mRNAs in the presence and absence of regulatory proteins. Some of these deficiencies could be redressed by targeted spending - for example, by contracts to biotechnology companies equipped to make and analyze cDNA clones from long, nonabundant viral mRNAs. Those in control of the considerable sums now available for the study of human retroviruses should consider such means to shore up the foundations of the vibrant enterprise reviewed here.

\section{References}

Arya, S.K., C. Guo, S.F. Josephs, and F. Wong-Staal. 1985. Trans-activator gene of human T-lymphotropic virus type III (HTLV-III). Science 229: 69-73.

Brady, J., K.T. Jeang, J. Duvall, and G. Khoury. 1987. Identification of p40x-responsive regulatory sequences within the human T-cell leukemia virus type I long terminal repeat. J. Virology 61: 2175-2181.

Chen, I.S.Y., A.J. Cann, N.P. Shah, and P.B. Gaynor. 1985a. Functional relationship between HTLV-2 $x$ and adenovirus E1A proteins in transcriptional activation. Science 230: $570-573$.

Chen, I.S.Y., D.J. Slamon, J.D. Rosenblatt, N.P. Shah, S.G. Quan, and W. Wachsman. 1985b. The X gene is essential for HTLV replication. Science 299: 54-58.

Cross, S., M.B. Feinberg, J. Solf, N. Holbrook, F. Wong-Staal, and W. Leonard. 1987. Regulation of the human interleukin- 2 receptor $\alpha$ chain promoter: Activation of a nonfunctional promoter by the transactivator gene of HTLV-1. Cell 49: 47-56.
Cullen, B.R. 1986. Trans-activation of human immunodeficiency virus occurs via a bimodal mechanism. Cell 46: 973982.

Dayton, A.I., J.G. Sodroski, C.A. Rosen, W.C. Goh, and W.A. Haseltine. 1986. The trans-activator gene of the human $T$ cell lymphotropic virus type III is required for replication. Cell 44: 941-947.

Dinter, H., R. Chiu, M. Imagawa, M. Karin, and K.A. Jones. 1987. In vitro activation of the HIV-1 enhancer in extracts from cells treated with a phorbol ester tumor promoter. $E M B O$ /. 6: 4067-4071.

Emerman, M., M. Guyader, L. Montagnier, D. Baltimore, and M.A. Muesing. 1987. The specificity of the human immunodeficiency virus type 2 transactivator is different from that of human immunodeficiency vinus type 1. EMBO $I$. 6: $3755-3760$.

Farmerie, W.G., D.D. Loeb, N.C. Casavant, C.A. Hutchison III, M.H. Edgell, and R. Swanstrom. 1987. Expression and processing of the AIDS virus reverse transcriptase in Escherichia coli. Science 236: 305-307.

Feinberg, M.B., R.F. Jarrett, A. Aldovini, R.C. Gallo, F. WongStaal. 1986. HTLV-III expression and production involve complex regulation at the levels of splicing and translation of viral RNA. Cell 46: 807-817.

Felber, B.K., H. Paskalis, C. Kleinman-Ewing, F. Wong-Staal, and G.N. Pavlakis. 1985. The $p X$ protein of HTLV-1 is a transcriptional activator of its long terminal repeats. Science 229: 675-679.

Fisher, A.G., B. Ensoli, L. Ivanoff, M. Chamberlain, S. Petteway, L. Ratner, R.C. Gallo, and F. Wong-Staal. 1987. The sor gene of HIV-1 is required for efficient virus transmission in vitro. Science 237:888-892.

Fisher, A.G., M.B. Feinberg, S.F. Josephs, M.E. Harper, L.M. Marselle, G. Reyes, M.A. Gonda, A. Aldovini, C. Debouk, R.C. Gallo, and F. Wong-Staal. 1986. The trans-activator gene of HTLV-III is essential for virus replication. Nature 320: $367-370$.

Frankel, A.D., D.S. Bredt, and C.O. Pabo. 1988. Tat protein from human immunodeficiency virus forms a metal-linked dimer. Science 240: 70-73.

Franza, B.R., S.F. Josephs, M.Z. Gilman, W. Ryan, and B. Clarkson. 1987. Characterization of cellular proteins recognizing the HIV enhancer using a microscale DNA-affinity precipitation assay. Nature 330: 391-395.

Fujisawa, J., M. Seiki, T. Kiyokawa, and M. Yoshida. 1985. Functional activation of long terminal repeat of human $\mathrm{T}$ cell leukemia virus type I by trans-acting factor. Proc. Natl. Acad. Sci. 82: 2277-2281.

Gallo, R., F. Wong-Staal, L. Montagnier, W. Haseltine, and M. Yoshida. 1988. HIV/HTLV gene nomenclature. Nature 333: 504-505.

Garcia, J.A., F.K. Wu, R. Mitsuyasu, and R.B. Gaynor. 1987. Interactions of cellular proteins involved in the transcriptional regulation of the human immunodeficiency virus. EMBO $J$. 6: $3761-3770$.

Gendelman, H.E., W. Phelps, L. Feigenbaum, J.M. Ostrove, A. Adachi, P.M. Howley, G. Khoury, H.S. Ginsberg, and M.A. Martin. 1986. Trans-activation of the human immunodeficiency virus long terminal repeat sequence by DNA viruses. Proc. Natl. Acad. Sci. 83: 9759-9763.

Guy, G., M.P. Kieny, Y. Riviere, C. LePeuch, K. Dott, M. Girard, R. Montagnier, and J.P. Lecocq. 1987. HIV F/3' orf encodes a phosphorylated GTP-binding protein resembling an oncogene product. Nature 330: 266-268.

Hauber, J. and B. Cullen. 1988. Mutational analysis of the trans-activation-responsive region of the human immuno- 
deficiency virus type I long terminal repeat. I. Virol. 62: 673-679.

Hauber, J., A. Perkins, E.P. Heimer, and B.R. Cullen. 1987. Trans-activation of human immunodeficiency virus gene expression is mediated by nuclear events. Proc. Natl. Acad. Sci. 84: 6364-6369.

Hidaka, M., J. Inoue, M. Yoshida, and M. Seiki. 1988. Post-transcriptional regulator (rex) of HTLV-1 initiates expression of viral structural proteins but supresses expression of regulatory proteins. EMBO I. 7: 519-523.

Hinrichs, S.H., M. Nerenberg, R.K. Reynolds, G. Khoury, and G. Jay. 1987. A transgenic mouse model for human neurofibromatosis. Science 237: 1340-1343.

Inoue, J., M. Seiki, T. Taniguchi, S. Tsuru, and M. Yoshida. 1986a. Induction of interleukin-2 receptor gene expression by $\mathrm{p}^{\mathrm{x}}$ encoded by human T-cell leukemia virus type 1 . $E M B O$ I. 5: 2883-2888.

Inoue, J., M. Seiki, and M. Yoshida. 1986b. The second $p X$ product $\mathrm{p} 27 \mathrm{x}$-III of HTLV-1 is required for gag gene expression. FEBS Lett. 209: 187-190.

Inoue, J., M. Yoshida, and M. Seiki. 1987. Transcriptional (p40 ${ }^{\mathrm{x}}$ ) and post-transcriptional $\left(\mathrm{p} 27^{\mathrm{x}}\right.$-III) regulators are required for the expression and replication of human T-cell leukemia virus type I genes. Proc. Natl. Acad. Sci. 84: 3653-3657.

Jacks, T., M.D. Power, F.R. Masiarz, P.A. Luciw, P.J. Barr, and H.E. Varmus. 1988. Characterization of ribosomal mutations in HIV-1 gag-pol expression. Nature 331: 280-283.

Jones, K.A., J.J. Kadonaga, P.A. Luciw, and R. Tijan. 1986. Activation of AIDS retrovirus promoter by the cellular transcription factor, Sp1. Science 232: 755-758.

Jones, K.A., P.A. Luciw, and N. Duchange. 1988. Structural arrangements of transcription control domains within the 5 untranslated leader regions of the HIV-1 and HIV-2 promoters. Genes Dev. 2: 1101-1114.

Kao, S.Y., A.F. Calman, P.A. Luciw, and M.B. Peterlin. 1987. Anti-termination of transcription within the long terminal repeat of HIV by tat gene product. Nature 330: 489-493.

Kaufman, J.D., G. Valandra, G. Rodriquez, G. Bushar, C. Giri, and M.A. Norcross. 1987. Phorbol ester enhances human immunodeficiency virus-promoted gene expression and acts on a repeated 10-base-pair functional enhancer element. Mol. Cell Biol. 7: 3759-3766.

Luciw, P.A., C. Cheng-Mayer, and J.A. Levy. 1987. Mutational analysis of the human immunodeficiency virus: the orf-B region down-regulates virus replication. Proc. Natl. Acad. Sci. 84: 1434-1438.

Maddon, P.J., A.G. Dalgleish, J.S. McDougal, P.R. Clapham, R.A. Weiss, and R. Axel. 1986. The T4 gene encodes the AIDS virus receptor and is expressed in the immune system and the brain. Cell 47: 333-348.

Maruyama, M., H. Shibuya, H. Harada, M. Hatakeyama, M. Seiki, T. Fujita, J. Inoue, M. Yoshida, and T. Taniguchi. 1987. Evidence for aberrant activation of the interleukin-2 autocrine loop by HTLV-1 encoded $\mathrm{p} 40^{\mathrm{x}}$ and T3/Ti complex triggering. Cell 48: $343-350$.

Mosca, J.D., D.P. Bednairk, N.B.K. Raj, C.A. Rosen, J.G. Sodroski, W.A. Haseltine, and P.M. Pitha. 1987. Herpes simplex virus type-1 can reactivate transcription of latent human immunodeficiency virus. Nature 325: 67-70.

Muesing, M.A., D.H. Smith, and D.J. Capon. 1987. Regulation of mRNA accumulation by a human immunodeficiency virus trans-activator protein. Cell 48: 691-701.

Nabel, G. and D. Baltimore. 1987. An inducible transcription factor activates expression of human immunodeficiency virus in T-cells. Nature 326: 711-713.

Nagashima, K., M. Yoshida, and M. Seiki. 1986. A single species of $p X$ mRNA of HTLV-1 encodes trans-activator p40 phosphoproteins. J. Virol. 60: 394-399.

Okamoto, T. and F. Wong-Staal. 1986. Demonstration of virusspecific transcriptional activator(s) in cell infected with HTLV-III by an in vitro cell-free system. Cell 47: 29-35.

Paskalis, H., B.K. Felber, and G. Pavlakis. 1986. Cis-acting sequences responsible for the transcriptional activation of human T-cell leukemia virus type I constitute a conditional enhancer. Proc. Natl. Acad. Sci. 83: 6558-6562.

Rice, A.P. and M.B. Matthews. 1988. Transcriptional but not translational regulation of HIV-1 by the tat gene product. Nature 332: $551-553$.

Rosen, C.A., J.G. Sodroski, and W.A. Haseltine. 1985. The location of cis-acting regulatory sequences in the human $\mathrm{T}$ cell lymphotropic virus type III (HTLV-III) long terminal repeat. Cell 41: 813 .

Rosen, C.A., J.G. Sodroski, W.C. Goh, A.I. Dayton, J. Lippke, and W.A. Haseltine. 1986. Post-transcriptional regulation accounts for the trans-activation of HTLV-III. Nature 319: 555-559.

Rosen, C.A., E. Terwilliger, A. Dayton, J.G. Sodroski, and W.A. Haseltine. 1988. Intragenic cis-acting art gene-responsive sequences of the human immunodeficiency virus. Proc. Natl. Acad. Sci. 85: 2071-2076.

Rosenblatt, J.D., A.J. Cann, D.J. Slamon, I.S. Smalberg, N.P. Shah, J. Fujii, W. Wachman, and I.S.Y. Chen. 1988. HTLV-II transactivation is regulated by the overlapping tax/rex nonstructural genes. Science 240: 916-919.

Sadaie, M.R., T. Benter, and F. Wong-Staal. 1988. Site-directed mutagenesis of two trans-regulatory genes (tat-III, trs) of HIV-1. Science 239: 910-913.

Seiki, M., S. Hattori, Y. Hirayama, and M. Yoshida. 1983. Human adult T-cell leukemia virus: complete nucleotide sequence of the provirus genome integrated in leukemia cell DNA. Proc. Natl. Acad. Sci. 80: 3618-3622.

Sen, R. and D. Baltimore. 1986. Inducibility of $k$ immunoglobulin enhancer-binding protein NF-KB by a post translational mechanism. Cell 47: 921-928.

Siekevitz, M., S.F. Josephs, M. Dukovich, N. Peffer, F. WongStaal, and W. Greene. 1987a. Activation of the HIV-1 LTR by $\mathrm{T}$ cell mitogens and the trans-activator protein of HTLVI. Science 238: 1575-1578.

Siekevitz, M., M.B. Feinberg, N. Holbrook, F. Wong-Staal, and W.C. Greene. 1987b. Activation of interleukin 2 and interleukin 2 receptor ( $\mathrm{Tac}$ ) promoter expression by the trans-activator (tat) gene product of human T-cell leukemia virus, Type I. Proc. Natl. Acad. Sci. 84: 5389-5393.

Sodroski, J.G., C.A. Rosen, and W.A. Haseltine. 1984. Transacting transcriptional activation of the long terminal repeat of human $\mathrm{T}$ lymphotropic viruses in infected cells. Science 225: 381-385.

Sodroski, J.G., C. Rosen, F. Wong-Staal, Z.S. Salahuddin, M. Popovic, S. Arya, R. Gallo, and W.A. Haseltine. 1985a. Transacting transcriptional regulation of human T-cell leukemia virus type III long terminal repeat. Science 227: 171-173.

Sodroski, J.G., R. Patarca, C. Rosen, and W.A. Haseltine. 1985b. Location of the trans-activating region on the genome of HTLV-III. Science 229: 74-77.

Sodroski, J.G., W.C. Goh, C. Rosen, A. Dayton, E. Terwilliger, and W.A. Haseltine. 1986. A second post-transcriptional trans-activator gene required for HTLV-III replication. $\mathrm{Na}$ ture 321: 412-417.

Strebel, K., D. Daugherty, K. Clouse, D. Cohen, T. Folks, and M.A. Martin. 1987. The HIV " $\mathrm{A}$ " (sor) gene product is essential for virus infectivity. Nature 328: 728-730.

Valerie, K., A. Delers, C. Bruck, C. Thiriart, H. Rosenberg, C. 
Deouck, and M. Rosenberg. 1988. Activation of human immunodeficiency virus type 1 by DNA damage in human cells. Nature 333: 78-81.

Varmus, H.E. and P.O. Brown. 1988. Retroviruses. In Mobile $D N A$ (ed. M. Howe and D. Berg). American Society for Microbiology. (in press).

Varmus, H.E. and R. Swanstrom. Replication of retroviruses. 1982. Chapter 5 in Molecular biology of tumor viruses, Part III, RNA tumor viruses (ed. R. Weiss, N. Teich, H.E. Varmus, and J. Coffin), pp. 369-512. Cold Spring Harbor Laboratory, Cold Spring Harbor, New York.

. Replication of retroviruses. 1985. Chapter 5 Supplement in Molecular biology of tumor viruses, RNA tumor viruses (ed. R. Weiss, N. Teich, H.E. Varmus, and J. Coffin), pp. 75-134. Cold Spring Harbor Laboratory, Cold Spring Harbor, New York.

Wu, F., J. Garcia, R. Mitsuyasu, and R. Gaynor. 1988. Alterations in binding characteristics of the human immunodeficiency virus enhancer factor. J. Virol. 62: 218-225.

Yoshida, M. and M. Seiki. 1987. Recent advances in the molecular biology of HTLV-1: trans-activation of viral and cellular genes. Annu. Rev. Immunol. 5: 541-559. 


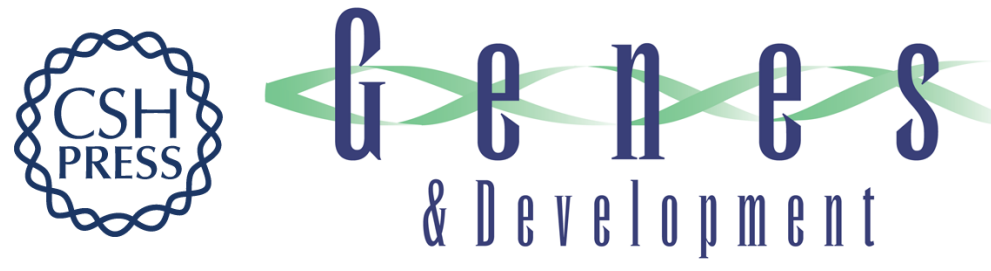

\section{Regulation of HIV and HTLV gene expression.}

H Varmus

Genes Dev. 1988, 2:

Access the most recent version at doi:10.1101/gad.2.9.1055 $\begin{array}{ll}\text { References } & \begin{array}{l}\text { This article cites } 59 \text { articles, } 28 \text { of which can be accessed free at: } \\ \text { http://genesdev.cshlp.org/content/2/9/1055.full.html\#ref-list-1 }\end{array}\end{array}$

\section{License}

Email Alerting

Receive free email alerts when new articles cite this article - sign up in the box at the top Service right corner of the article or click here.

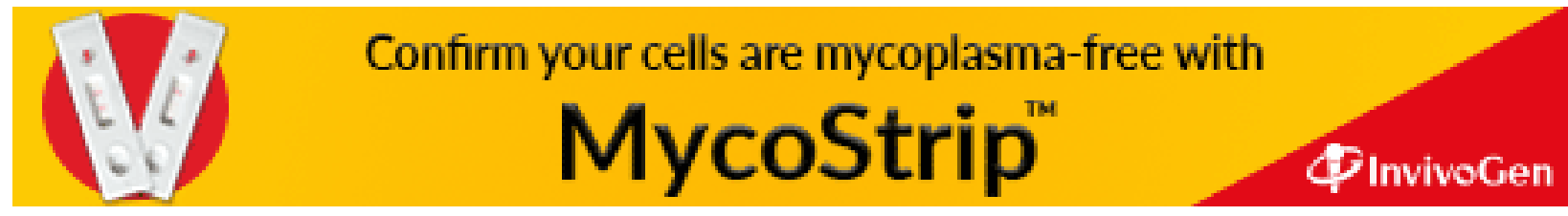

